\title{
THE EFFECT OF LEARNING MOTIVATION AND SELF- CONCEPT ON MATHEMATICAL PROBLEMS
}

\author{
Baso Intang Sappaile ${ }^{1)}$, Triyanto Pristiwaluyo ${ }^{2)}$ \\ ${ }^{1}$ FMIPA Universitas Negeri Makassar \\ ${ }^{2}$ FIP Universitas Negeri Makassar \\ E-mail: baso.sappaile@unm.ac.id
}

\begin{abstract}
This research is a survey research that is focused on the ability of students to solve mathematical problems. The purpose of the study was to determine the relationship between learning motivation and self-concept of students with the ability to solve mathematical problems, both together and individually. The population of the study is 2017/2018 odd semester students of Mathematics Education Study Program FMIPA UNM Makassar. Sampling is used random class. Data obtained through instruments: 1) learning motivation scale, 2) self concept scale, 3) test mathematical problem solving ability. Data were analyzed by multiple regression. The conclusions obtained are 1) learning motivation has a positive relationship with mathematical problem solving abilities, 2) self-concept has a positive relationship with mathematical problem solving abilities, and 3) contribution of motivation and selfconcept to mathematical problem solving by $71 \%$. It is expected that other researchers to expand the population and add independent variables that theoretically adhere to mathematical problem solving abilities.
\end{abstract}

Keywords: Motivation, self-concept, problem solving, mathematics.

\section{PENDAHULUAN}

Salah satu misi program $\mathrm{S} 1$ pendidikan matematika adalah menyelenggarakan pendidikan dan pengajaran untuk menghasilkan pendidik yang memiliki kompetensi berdaya saing nasional, mampu mengembangkan diri, tanggap, dan mampu mengikuti dan menyesuaikan diri terhadap perubahan dan kemajuan IPTEK serta inovasi dan pergeseran paradigma di bidang pendidikan, khususnya yang menyangkut pendidikan matematika.

Mengingat pentingnya matematika, maka sangat diharapkan mahasiswa dapat memecahkan masalah matematika. Disamping matematika sebagai sarana berpikir ilmiah yang sangat diperlukan oleh mahasiswa, juga untuk mengembangkan kemampuan berpikir logiknya yang dapat memecahkan masalah matematika dan masalah dunia nyata. Pemecahan masalah matematika juga diperlukan untuk menunjang keberhasilan belajar mahasiswa dalam menempuh jenjang pendidikan yang lebih tinggi dan masalah karir mahasiswa.

Di lain pihak kenyataan menunjukkan bahwa hasil belajar mahasiswa program studi pendidikan matematika FMIPA UNM semester ganjil tahun akademik 2017/2018, khusunya mata kuliah dasar dengan rata-rata 67,3. Jika kita kategorikan 86-100, 71-85, 56-70, 41-55 berturut-turut tinggi, sedang, rendah, dan sangat rendah, hal ini dapat dikatakan hasil belajar mahasiswa rendah.

Keadaan ini merupakan suatu tantangan bagi yang berkecimpung di bidang pendidikan, terutama para ahli pendidikan matematika dan ahli penilaian untuk memberikan sumbangan pemikiran dalam usaha meningkatkan kemampuan 
berpikirnya, khususnya di jurusan pendidikan matematika FMIPA UNM Makassar. Dengan demikian diperlukan suatu usaha untuk meningkatkan kemampuan berpikir mahasiswa khususnya dalam memecahkan masalah matematika dan dunia nyata.

Masalah dalam penelitian ini, yaitu 1) apakah motivasi belajar mempunyai hubungan positif dengan kemampuan pemecahan masalah matematika? 2) apakah konesp diri mempunyai hubungan positif dengan kemampuan pemecahan masalah matematika? dan 3) apakah motivasi belajar dan konsep diri secara bersama-sama mempunyai hubungan dengan kemampuan pemecahan masalah matematika?

Motivasi belajar mahasiswa, sudah merupakan kodrat bagi setiap manusia sebagai mahluk hidup bahwa dalam dirinya terdapat dorongan-dorongan untuk melakukan sesuatu, misalnya "dorongan ingin tahu" sesuatu. Daya pendorong untuk melakukan sesuatu itu seringkali disebut dengan "motif". Motif bukanlah hal yang dapat diamati, tetapi adalah hal yang dapat disimpulkan adanya karena sesuatu yang dapat disaksikan.

Drever (dalam Slameto, 1991) mengatakan "motive is an affectiveconative factor which operates in determining the direction of an individual's behavior towards an end or goal consiustly apprehended or unconsiustly". Dari definisi ini dapat dipahami bahwa motif erat kaitannya dengan tujuan yang akan dicapai. Di dalam menentukan tujuan itu dapat disadari atau tidak, akan tetapi untuk mencapai tujuan itu perlu berbuat. Sedangkan penyebab berbuat adalah motif itu sendiri sebagai daya pendorongnya atau penggeraknya.

Winkel (1984) mendefinisikan motif sebagai daya penggerak dari dalam diri individu yang mendorongnya yang melakukan kegiatan-kegiatan tertentu untuk mencapai sesuatu tujuan. Jadi motif merupakan kondisi intern atau disposisi (kesiagaan atau kecenderungan) seseorang. Sejalan dengan Suryabrata (1987) yang mengatakan motif adalah dalam diri individu yang mendorongnya untuk melakukan kegiatan-kegiatan tertentu untuk mencapai sutau tujuan. Sedang Gerungan (1978) mengatakan motif pada manusia merupakan dorongan, keinginan, hasrat, dan tenaga penggerak lainnya yang berasal dari dalam dirinya untuk melakukan sesuatu.

Berdasarkan pengertian-pengertian di atas, dapat dikatakan bahwa motif adalah segala sesuatu yang timbul dari dalam diri individu yang mendorongnya untuk melakukan kegiatan-kegiatan tertentu untuk mencapai sesuatu tujuan. Setiap kegiatan mempunyai motifnya sendiri. Suatu motif selalu mempunyai tujuan. Sedang tujuan menjadi arah sesuatu kegiatan yang mermotif. Dalam kehidupan nyata motif sering dinyatakan dengan berbagai istilah, seperti hasrat, maksud, tekad, kemauan, kehendak, kebutuhan, cita-cita, kehausan, kesediaan, dan sebagainya.

Motif dan motivasi merupakan dua hal yang tidak dapat dipisahkan, namun secara konseptual dapat dibedakan karena motivasi merupakan hal-hal yang berkaitan dengan timbulnya dan aktifnya motif. Sardiman (1992) mengatakan bahwa berawal dari kata motif maka motivasi dapat diartikan sebagai daya penggerak yang telah menjadi aktif. Motif menjadi aktif pada saat-saat tertentu, terutama bila untuk mencapai tujuan terasa sangat mendesak. 
Hudojo (1990) mengatakan bahwa kekuatan pendorong yang ada di dalam diri seseorang untuk melakukan aktivitas-aktivitas tertentu untuk mencapai sesuatu tujuan disebut "motif". Sedangkan segala sesuatu yang berkaitan dengan timbulnya dan berlangsungnya motif itu disebut "motivasi". Hal ini berarti bahwa dibalik setiap aktivitas seseorang terdapat sesuatu motivasi mendorongnya untuk mencapai sesuatu tujuan tertentu.

Motivasi sebagai proses pembangkitan gerak dalam diri individu untuk melakukan atau berbuat sesuatu guna mencapai suatu tujuan mempunyai tiga fungsi, yaitu menggerakkan, mengerahkan, dan menyeleksi perbuatan individu. Motivasi selalu berkaitan erat dengan tujuan. Motivasi melepaskan energi karena setiap kegiatan selalu memerlukan energi. Motivasi bukanlah sesuatu yang statis, tetapi dapat diubah dan ditingkatkan intensitasnya oleh lingkungan.

Motivasi belajar seseorang manakala memiliki dorongan untuk maju dengan maksud berprestasi seoptimal mungkin. Motivasi belajar dapat tumbuh karena memiliki motivasi berprestasi. Murray (dalam Koeswara, 1986) mendefinisikan kebutuhan untuk berprestasi sebagai hasrat seseorang untuk mengerjakan sesuatu yang sulit sebaik dan secepat mungkin.

Mehta (dalam Sadli, 1986) mengemukakan karakteristik orang yang mempunyai motivasi berprestasi tinggi, yaitu (1) memiliki kecenderungan untuk memiliki resiko yang sedang dan diperhitungkan, serta harapan dan tujuan realistis untuk dicapai, (2) menyenangi situasi kerja yang meminta tanggung jawab pribadi, (3) selalu menambah pengetahuan dalam hal cara kerja yang baik, dan (4) menyelidiki lingkungan dan sumber-sumber yang ada, serta belajar dengan cara yang unik dan inovatif.

Eysenck dan Wilson (1975) mengemukakan bahwa orang yang memiliki motivasi berprestasi tinggi mempunyai karakteristik antara lain (1) berambisi, (2) berkompentisi, (3) bekerja keras, (4) tekun berusaha meningkatkan status sosialnya, dan (5) memberi penilaian yang tinggi terhadap kreativitas dan produktivitas.

Berdasarkan uraian yang dikemukakan di atas, maka yang dimaksudkan motivasi belajar dalam penelitian ini adalah motivasi berprestasi yang memiliki daya penggerak dari dalam diri siswa yang mendorongnya untuk mencapai prestasi belajar setinggi mungkin berdasarkan standar keunggulan tertentu.

Dalam hal konsep diri mahasiswa, manusia sebagai mahluk sosial juga merupakan mahluk individu. Manusia sebagai mahluk individu, selain dapat menanggapi dan menilai orang lain juga dapat menanggapi dan menilai dirinya sendiri. Hal ini dapat terjadi karena manusia memiliki kemampuan merefleksi dirinya sendiri. Tanggapan dan penilaian individu terhadap dirinya sendiri biasa disebut dengan istilah "konsep diri (self-concept)".

Konsep diri merupakan pandangan dan sikap individu terhadap keseluruhan keadaan dirinya, baik yang bersifat fisik maupun yang bersifat psikis. Konsep diri bukanlah merupakan bawaan sejak lahir, melainkan dipelajari dan terbentuk melalui kontak sosial dan pengalaman individu. Oleh 
karena pandangan individu tentang dirinya dipengaruhi oleh bagaimana individu mengartikan pandangan orang lain tentang dirinya.

Pemecahan masalah matematika, masalah matematika itu sendiri merupakan pertanyaan, baik pertanyaan dalam matematika, pertanyaan dengan matematika, maupun pertanyaan dengan pemikiran matematika yang belum ditemukan jawabannya dengan segera.

Hudoyo (1990) menyatakan bahwa suatu pertanyaan akan merupakan suatu masalah hanya jika seseorang tidak mempunyai aturan/hukum tertentu yang segera dapat dipergunakan untuk menemukan jawaban pertanyaan tersebut. Selanjutnya, Polya (1956) menyatakan bahwa masalah harus baik, dalam hal bukan yang terlalu sulit dan tidak terlalu mudah, menarik dan alami.

Tugas atau soal pemecahan masalah dapat diberikan dalam bentuk individu atau kelompok. Pekerjaan rumah yang diberikan kepada siswa berarti memberi kesempatan kepada siswa untuk mendapatkan pengertian yang luas tentang topik-topik dan konsep-konsep yang telah diajarkan di dalam kelas dan menyediakan sebuah pola dalam menganalisis materi secara lebih mendalam.

Pemecahan masalah matematika memuat "pemecahan masalah" sebagai perilaku kognitif dan "matematika" sebagai objek yang dipelajari. Proses berpikir dalam pemecahan masalah matematika memerlukan kemampuan intelek tertentu yang akan mengorganisasi strategi yang ditempuh sesuai dengan data dan permasalahan yang dihadapi. Oleh karena itu dapat dipahami bahwa penguasaan pemecahan masalah terlebih dahulu dituntut penguasaan aspek kognitif yang lebih rendah, yaitu ingatan, pemahaman, dan aplikasi.

Polya (1956) mengembangkan empat langkah penting dalam strategi pemecahan masalah, yaitu memahami masalah, mencari alternatif penyelesaian, melakukan perhitungan, dan memeriksa ulang hasil perhitungan.

Ibrahim dan Nur (2000) menyatakan bahwa pembelajaran berdasar masalah biasanya terdiri dari lima tahap utama yang dimulai dengan guru memperkenalkan siswa dengan suatu situasi masalah dan diakhiri dengan penyajian dan analisis hasil kerja siswa. Jika jangkuan masalahnya sedang-sedang saja kelima tahapan mungkin saja diselesaikan dua atau tiga kali pertemuan.

Dengan demikian pemecahan suatu masalah diperlukan kegiatan mental yang tinggi dengan pola yang terurut, yaitu merumuskan masalah, menelaah masalah, merumuslan hipotesis, mengumpulkan dan mengelompokkan data, pembuktian hipotesis, dan menentukan pilihan penyelesaian.

Berdasarkan kajian teori dan hasil-hasil penelitian yang relevan di atas, maka dirumuskan hipotesis penelitian, yaitu: 1) motivasi belajar dan konsep diri secara bersama-sama mempunyai hubungan dengan kemampuan pemecahan masalah matematika, 2) motivasi belajar mempunyai hubungan positif dengan kemampuan pemecahan masalah matematika, dan 3) konsep diri mempunyai hubungan positif dengan kemampuan pemecahan masalah matematika.

Penelitian ini bertujuan untuk mengetahui apakah: 1) motivasi belajar dan konsep diri secara bersama-sama mempunyai hubungan dengan kemampuan pemecahan masalah matematika, 2) motivasi belajar mempunyai hubungan positif dengan kemampuan pemecahan masalah matematika, dan 3) konsep diri 
mempunyai hubungan positif dengan kemampuan pemecahan masalah matematika.

Manfaat penelitian ini yaitu: 1) bagi mahasiswa sebagai bahan sumber pemikiran tentang keterkaitan antara motivasi belajar, konsep diri, dan kemampuan pemecahan masalah matematika, dan 2) bagi dosen UNM khususnya dosen matematika yang mengajarkan mata kuliah matematika khususnya, dapat digunakan dalam mengoptimalkan proses pembelajaran di dalam kelas.

\section{METODE PENELITIAN}

Penelitian ini merupakan jenis penelitian ex-post facto dengan melibatkan dua varibel bebas dan satu variabel tak-bebas. Motivasi belajar dan konsep diri sebagai variabel bebas dan kemampuan pemecahan masalah matematika sebagai variabel tak-bebas.

Penelitian dilakukan di Jurusan Pendidikan Matematika FMIPA UNM Makassar. Populasi penelitian adalah semua mahasiswa progran studi pendidikan matematika semester genap tahun 2017/2018 FMIPA UNM Makassar. Teknik pengambilan sampel dengan random kelas dan terandom adalah kelas A2 yang terdiri dari 30 mahasiswa.

Pengumpulan data digunakan skala dan instrumen tes. Skala digunakan untuk pengumpulan data motivasi belajar, dan data konsep diri. Sedang instrumen tes digunakan untuk pengumpulan data kemampuan pemecahan masalah matematika.

Analisis data yang digunakan adalah statistik inferensial dengan model persamaan regresi ganda. Persamaan model regresi yang digunakan adalah: $\overleftrightarrow{Y}=\gamma o+\gamma 1 X 1+\gamma 2 \times 2+\varepsilon$ dengan persamaan regresi ganda, yaitu $Y=\gamma o+\gamma 1 X 1+\gamma 2 X 2$

Kontelasi ketiga variabel penelitian ditunjukkan pada gambar 1 berikut.

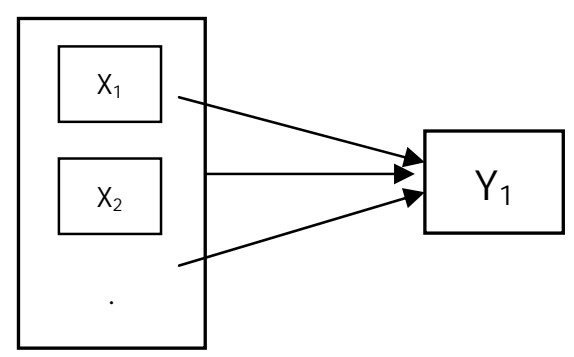

Gambar 1. Kontelasi Penelitian

Keterangan:

$\mathrm{X}_{1}$ : motivasi belajar

$\mathrm{X}_{2}$ : konsep diri

$\mathrm{Y}$ : kemampuan pemecahan masalah 


\section{HASIL PENELITIAN DAN PEMBAHASAN}

\section{Hasil Penelitian}

1. Motivasi belajar dan konsep diri secara bersama-sama mempunyai hubungan dengan kemampuan pemecahan masalah matematika.

Hipotesis statistik yang diuji:

$$
\begin{aligned}
& \mathrm{H}_{\mathrm{o}}: \gamma 1=\gamma 2=0 \\
& \mathrm{H}_{1}: \text { Bukan } \mathrm{H}_{0}
\end{aligned}
$$

Berdasarkan tabel-1 dan tabel-2 dengan $\mathrm{F}_{\text {hitung }}=32,952$ dan nilai- $\mathrm{p}=0,0001<\alpha=$ 0,05 maka Ho ditolak atau $\mathrm{H}_{1}$ diterima. Dengan demikian dapat dinyatakan bahwa motivasi belajar dan konsep diri secara bersama-sama mempunyai hubungan dengan kemampuan pemecahan masalah matematika dengan kontribusi sebesar $71 \%$.

Tabel 1. ANOVA

\begin{tabular}{ccccccc}
\hline & $\begin{array}{c}\text { Sum of } \\
\text { Squares }\end{array}$ & Df & $\begin{array}{c}\text { Mean } \\
\text { Square }\end{array}$ & F & Sig. \\
\hline Regression & 7013,422 & 2 & 3506,711 & 32,952 & 0,000 \\
\hline Residual & 2873,278 & 27 & 106,418 & & \\
\hline Total & 9886,700 & 29 & & & \\
\hline
\end{tabular}

a. Predictors: (Constant), X2, X1

b. Dependent Variable: Y

Tabel 2. Model Summary

\begin{tabular}{c|c|cl}
\hline R & R Square & $\begin{array}{c}\text { Adjusted R } \\
\text { Square }\end{array}$ & $\begin{array}{l}\text { Std. Error of the } \\
\text { Estimate }\end{array}$ \\
\hline 0,842 & 0,709 & 0,688 & 10,32 \\
\hline
\end{tabular}

a. Predictors: (Constant), X2, X1

2. Motivasi belajar mempunyai hubungan positif dengan kemampuan pemecahan masalah matematika.

$$
\begin{aligned}
& \mathrm{H}_{0}: \gamma 1 \leq 0 \\
& \mathrm{H}_{1}: \gamma 1>0
\end{aligned}
$$

Berdasarkan tabel-3 dengan $t_{\text {hitung }}=3,735$ dan nilai-p $=\frac{0,001}{2}=0,0001<\alpha=0,05$ maka Ho ditolak atau $\mathrm{H}_{1}$ diterima. Dengan demikian dapat dinyatakan bahwa

\begin{tabular}{|c|c|c|c|c|c|}
\hline & $\begin{array}{l}\text { Unstandardized } \\
\text { Coefficients }\end{array}$ & & $\begin{array}{c}\text { Standardize } \\
\mathrm{d} \\
\text { Coefficients }\end{array}$ & $\mathrm{t}$ & Sig. \\
\hline & $\mathrm{B}$ & Std. Error & Beta & & \\
\hline (Constant) & $-100,718$ & 24,708 & & $-4,076$ &, 000 \\
\hline $\mathrm{X} 1$ & 2,910 & ,779 & ,476 & 3,735 & ,001 \\
\hline $\mathrm{X} 2$ & 1,130 & ,306 & ,471 & 3,694 & ,001 \\
\hline
\end{tabular}
motivasi belajar mempunyai hubungan positif dengan kemampuan pemecahan masalah matematika.

Tabel 3. Coefficients

a Dependent Variable: Y 
3. Konsep diri mempunyai hubungan positif dengan kemampuan pemecahan masalah matematika.

Hipotesis statistik yang dijui:

$$
\begin{aligned}
& \mathrm{H}_{0}: \gamma 1 \leq 0 \\
& \mathrm{H}_{1}: \gamma 1>0
\end{aligned}
$$

Berdasarkan tabel-3 dengan $\mathrm{t}_{\text {hitung }}=3,694$ dan nilai- $\mathrm{p}=\frac{0,001}{2}=0,0001<\alpha=0,05$ maka Ho ditolak atau $\mathrm{H}_{1}$ diterima. Dengan demikian dapat dinyatakan bahwa konsep diri mempunyai hubungan positif dengan kemampuan pemecahan masalah matematika.

\section{Pembahasan}

Berdasarkan hasil pengujian hipotesis motivasi belajar dan konsep diri secara bersama-sama mempunyai hubungan dengan kemampuan pemecahan masalah matematika dengan kontribusi sebesar $71 \%$. Hal ini menunjukkan bahwa motivasi belajar dan konsep diri relatif sangat besar pengaruhnya terhadap kemampuan pemecahan masalah matematika. Seseorang yang memiliki motivasi dan konsep diri tinggi tentunya tidak akan menglami kesulitan dalam belajarnya, baik dalam ilmu-ilmu sosial maupun dalam ilmu-ilmu alam. Hasil penelitian Darlia, dkk. (2016) disimpulkan bahwa kesulitan yang dialami oleh siswa dalam menyelesaikan soal keliling dan luas segiempat yaitu gangguan atau kekacauan belajar, ketidakmampuan belajar, ketidakfungsian belajar, pencapaian rendah dan lambat belajar.

Motivasi belajar mempunyai hubungan positif dengan kemampuan pemecahan masalah matematika. Seseorang dapat memiliki motivasi belajar mana kala tidak mengalami rintangan dalam belajar, misalnya belajar dalam kelas yang kondusif, suasana kelas merasa nyaman, sarana belajar atau sumber belajar memadai. Hasil penelitian Adiputra1 \& Mujiyati (2017) dikemukakan bahwa motivasi memberi kekuatan pada individu untuk memulai aktivitas. Kemunculan motivasi didahului oleh adanya kebutuhan dan dorongan yang membuat seseorang mampu melakukan sebuah kegiatan yang berdasarkan motif.

Faktor yang dapat mempengaruhi motivasi belajar yaitu sarana dan prasarana pembelajaran. Hasil penelitian Jannah dan Uep (2018) dikatakan bahwa sarana dan prasarana pembelajaran merupakan salah satu faktor yang mempengaruhi motivasi belajar siswa. Disamping faktor sarana dan prasarana, juga dipengaruhi oleh kecerdasan emosional dan media pembelajaran. Hasil penelitian Sari dan Budi (2018) disimpulkan bahwa kecerdasan emosional berpengaruh positif dan signifikan terhadap motivasi belajar siswa. Hasil penelitian Hikmawan dan Alit (2018), bahwa pemanfaatan media pembelajaran berbasis edmodo pada Sekolah Menengah Kejuruan (SMK) Swasta di Kota Cimahi berada pada kategori cukup kuat dalam mempengaruhi motivasi belajar siswa.

Ketidakmampuan belajar matematika akan mengalami kesulitan menemukan alternatif-alternatif menyelesaikan masalah, baik masalah matematika 
maupun masalah kehidupan lingkungan nyata. Hasil penelitian Kadikma, dkk. (2017) menyatakan bahwa siswa tidak mampu memenuhi indikator komponen kebaruan dikarenakan mereka tidak mampu menemukan alternatif penyelesaian masalah baru yang dapat digunakan untuk menyelesaikan masalah SPLDV yang diberikan.

Secara parsial, disamping motivasi belajar mempengaruhi kemampuan pemecahan masalah matematika, juga konsep diri mempunyai hubungan positif dengan kemampuan pemecahan masalah matematika. Pudjijogyanti (1988) mengemukakan bahwa konsep diri terbentuk atas dua komponen, yaitu komponen kognitif dan komponen afektif. Komponen kognitif merupakan pengetahuan individu tentang keadaan dirinya. Pengetahuan tersebut akan membentuk gambaran diri (self-picture) dan selanjutnya terbentuk citra diri (selfimage). Sedang komponen afektif merupakan penilaian individu terhadap dirinya. Penilaian tersebut akan membentuk penerimaan terhadap diri (selfacceptance) serta harga diri (self-esteem) individu. Dengan adanya konsep diri seseorang, maka dalam prinsipnya akan konsisten dalam menghadapi masalah. Kemampuan menyelesaikan masalah matematika diperlukan kekonsistenan dalam mengikuti langkah-langkah yang telah ditentukan, misalnya langkah-langkah pemecahan matematika yang dikemukakan oleh Polya.

Ilustrasi konsep diri, misalnya: apabila penulis diminta untuk memberi gambaran diri, maka akan tersusun daftar yang panjang, yaitu saya seorang pria, sudah menikah, guru matematika. Daftar gambaran diri tersebut dapat diperpanjang lagi dengan menguraikan bentuk tubuh, tujuan hidup, kesenangan dan sebagainya. Apabila dari ilustrasi tersebut, yaitu "saya seorang pria yang sudah menikah dengan profesi guru matematika" diteruskan dengan penilaian "saya puas dan senang dengan keadaan saya, karena saya mempunyai kedudukan terhormat di masyarakat", maka dapat dikatakan bahwa saya menilai diri saya baik, saya menerima diri saya positif, dan saya mempunyai harga diri yang positif.

Apabila membicarakan masalah konsep diri, maka tidak akan lepas dari masalah gambaran diri, citra diri, penerimaan diri, serta harga diri. Ini berarti konsep diri mempunyai peranan penting dalam menentukan prilaku individu, oleh karena bagaimana individu memandang dirinya akan tampak dari seluruh prilakunya. Dengan konsep diri, seseorang dapat menguasai aspek kognitif dan aspek afektif. Dengan aspek kognitif yang dikuasai tentukan objek-objek matematika juga dikuasai termasuk objek-objek yang ada dalam masalah matematika yang nantinya dapat memecahkan masalah matematika termasuk masalah lingkungan nyata.

\section{SIMPULAN DAN SARAN \\ Simpulan}

Berdasarkan hasil pembahasan dan pembahasan, maka kesimpulan dalam penelitian ini adalah: 1) motivasi belajar mempunyai hubungan positif dengan kemampuan pemecahan masalah matematika, 2) konsep diri mempunyai hubungan positif dengan kemampuan pemecahan masalah matematika, dan 3) 
kontribusi motivasi dan konsep diri terhadap pemecahan masalah matematika sebesar 71\% mahasiswa Program Studi Matematika FMIPA UNM Makassar.

Saran

Berdasarkan kesimpulan di atas, maka peneliti menyarankan beberapa hal yang perlu diperhatikan, yaitu sebagai berikut.

1. Bagi dosen pendidikan matematika; untuk meningkatkan kemampuan mahasiswa dalam pemecahan masalah matematika, seyogianya selalu memberikan motivasi kepada mahasiswa untuk lebih banyak belajar, khususnya belajar dalam bentuk latihan menyelesaikan masalah matematika.

2. Bagi mahasiswa program studi matematika; seyogianya lebih percaya diri dalam memilih teknik dalam menentukan langkah atau trik dalam menyelesaikan masalaha matematika dan masalah dunia nyata.

3. Bagi peneliti lain; disarankan untuk lebih memperbanyak variabel bebas dan memperluas populasi penelitian serta berbagai satuan tingkat pendidikan.

\section{DAFTAR PUSTAKA}

Adiputra1 \& Mujiyati. 2017. Motivasi dan Prestasi Belajar Siswa di Indonesia: Kajian Meta-Analisis. Jurnal Konselor. Volume 6 Number 4. 2017. ISSN: Print 1412-9760 - Online 2541-5948. DOI: https://doi.org/10.24036/ 02017648171-0-00

Darlia, dkk. 2016. Deskripsi Kesulitan Belajar dalam Menyelesaikan Soal-Soal Matematika Materi Pokok Keliling dan Luas Segiempat di Kelas VII SMP

Negeri 9 Kendari. Jurnal Penelitian Pendidikan Matematika Volume 4, No. 1, Januari 2016.

Eysenck, H.J., and Wilson, G. 1975. Know Your Own Personality, Penguin Books, London.

Gerungan,W.A. 1978. Psycologi Sosial, Suatu Ringkasan, PT. Eresco, Jakarta.

Hikmawan dan Alit. 2018. Pemanfaatan Media Pembelajaran Berbasis Edmodo terhadap Motivasi Belajar Siswa Sekolah Menengah Kejuruan. Jurnal Pendidikan Manajemen Perkantoran. Vol.1, No.2, Januari 2018.

Hudoyo, Herman. 1990. Strategi Mengajar Belajar Matematika, IKIP Malang, Malang.

Ibrahim, Muslimin., Mohmad Nur. 2000. Pengajaran Berdasarkan Masalah.

Unesa-Universitas Press, Surabaya.

Jannah dan Uep. 2018. Sarana dan Prasarana Pembelajaran sebagai Faktor

Determinan terhadap Motivasi Belajar Siswa. Jurnal Pendidikan Manajemen Perkantoran Vol.1, No.2, Januari 2018.

Kadikma. 2017. Proses Berpikir Kreatif Berdasarkan Komponen Kreativitas Pemecahan Masalah Siswa pada Materi SPLDV. Jurnal Vol. 8, No. 2.

Koeswara, E. 1986. Motivasi, Teori dan Penelitiannya, Angkasa, Bandung. Polya. 1956. How to Solve It. Standford University: John Wiley and Sons. Pudjijogyanti, Clara R. 1988. Konsep Diri dan Pendidikan, Arcan, Jakarta. Sadli, Saparinah. 1986. Intelegensi, Bakat dan Tes IQ, Gaya Favorit Press, Jakarta. 
Sardiman A. M. 1992. Interaksi dan Motivasi Belajar Mengajar Pedoman Bagi Guru dan Calon Guru, Rajawali pers, Jakarta.

Sari dan Budi. 2018. Upaya Meningkatkan Motivasi Belajar Siswa Melalui Kecerdasan Emosional. Jurnal Pendidikan Manajemen Perkantoran. Vol.1, No.2, Januari 2018.

Slameto, 1991, Belajar dan Faktor-Faktor Yang Mempengaruhinya, Rineka Cipta, Jakarta.

Suryabrata, Sumadi. 1987. Psikologi Pendidikan, CV. Rajawali, Jakarta.

Winkel, W. S. 1984. Psikologi Pendidikan dan Evaluasi Belajar, Usaha Nasional, Surabaya.

Yayuk. 2017. Penerapan Model STAD-Problem Solving untuk Meningkatkan Proses dan Hasil Belajar Siswa. Jurnal Ilmu Pendidikan, Volume 2 Nomor 1, Juni 2017.

Yulianti. 2018. Analysis of The Influence Learning Model on Mathematics Problem Solving Abilities to Class VIII Student at MTSN Model Makassar. Jurnal Inovasi Pendidikan Matematika, Volume 6 No. 2 Juli 2018 